\title{
Using ecological indicators in a whole-ecosystem wetland experiment
}

\author{
William J. Mitsch ${ }^{*}$, Naiming Wang ${ }^{*} 1$, Li Zhang ${ }^{*}$, Robert Deal ${ }^{* *}$, Xinyuan Wu ${ }^{* 2}$, and Andy Zuwerink ${ }^{*}$ \\ * Olentangy River Wetland Research Park, School of Natural Resources,352 W. Dodridge Street, The Ohio \\ ** State University, Columbus, Ohio, 43202, USA \\ * Department of Natural Science, Shawnee State University, Portsmouth, OH 45662, USA \\ 1 Present address: South Florida Water Management District PO Box 24680, West Palm Beach, FL 33416 \\ 2 Present address: Department of Rangeland Ecology and Management, Texas A\&M University, College \\ Station, TX 77843 USA
}

Published as: pp 211-236 in: S.E. Jørgensen, R. Costanza, and F.-L. Xu, eds. 2004. Handbook of Ecological Indicators for Assessment of Ecosystem Health, CRC Press, Boca Raton, FL.

\section{Abstract}

Indicators were used to estimate wetland divergence and convergence in a whole ecosystem experiment in central Ohio, USA. Two similar-geomorphology, 1-ha flow-through created wetland basins were maintained with similar inflow and water depth for 6 years. One basin was planted with 2,500 individual rootstocks of 13 species of macrophytes at the beginning of the 6-year study; the second basin was left unplanted. Both basins were then subjected to natural additional colonization of plants, algae, microbes, and animals. Macrophyte community diversity was estimated by a new community diversity index (CDI) and this was treated as the independent variable. By the sixth year, CDI diverged in the two wetlands with the "planted" basin supporting several macrophyte communities of mostly introduced species and the "unplanted" or "naturally colonizing" basin dominated by an invasive Typha spp. monoculture. With this difference in community diversity came a divergence in ecosystem structure and function. Sixteen indicators of wetland function (dependent variables) were observed annually and relative differences between the wetland basins were determined by a non-parametric similarity index. The basins were ecologically similar through years 3 through 5 , but by the sixth year of the experiment, the basins diverged in function with only $44 \%$ similarity after similarity between 75 and $87 \%$ for years 3 through 5 . The macrophyte-diverse wetland that resulted from planting had higher water column productivity, water temperature, dissolved oxygen, and $\mathrm{pH}$. The naturally colonizing Typha wetland had higher macrophyte productivity, benthic invertebrate diversity, outflow suspended sediments (turbidity), and dissolved ions (conductivity). Different bird, amphibian and fish use are also hypothesized as having resulted from the planting and differential colonization. Our large-scale, long-term, wholeecosystem findings dispute some findings of small-scale, short-term, replicated mesocosm experiments.

\section{Introduction}

Few studies have investigated how macrophyte diversity affects ecosystem function in created and restored wetlands, despite the frequent use of macrophyte cover and diversity as determinants of legal and ecological success of these wetlands in mitigating wetland loss, particularly in the USA ${ }^{1-5}$ Engelhardt and Ritchie ${ }^{6}$ manipulated seventy $1.5-$ $\mathrm{m}$ diameter wading pools with one, two, and three species of the submersed pondweed (Potamogeton spp.) and found that higher algal biomass and higher phosphorus uptake occurred in the pools with highest macrophyte species richness. They concluded that higher species richness created up to $25 \%$ higher algal biomass that caused $30 \%$ more phosphorus uptake and thus would support more wildlife and fish. They further concluded that a wetland with high richness or diversity due to disturbance might better "sustain ecosystem functioning and promote the services of those wetlands to humans."

Alternatives to the replicated small-scale mesocosms for wetland study are large-scale, long-term whole ecosystem studies that include more components of the ecosystem. Whole-ecosystem experiments, which have been carried out for terrestrial systems, ${ }^{7-10}$ lakes, ${ }^{11-14}$ and wetlands ${ }^{2,15-}$ ${ }^{16}$ are often criticized because the size, cost, and logistics alone do not allow for much if any replication. Some researchers suggest that there is no single optimum scale for ecosystem experimentation but state that it is easier to apply statistical methods successfully to many small replicated systems. ${ }^{17-18}$

We present here a 6-year, whole-ecosystem wetland experiment that illustrates: 1) the effect of macrophyte introduction and subsequent macrophyte community development on ecosystem function, and 2) the use of simple, easy-to-measure, indicators for assessing largescale, long-term, whole-ecosystem experiments in wetland ecology. Our study investigates the relationship between macrophyte community diversity and ecosystem function in light of current theories on biodiversity and ecosystem function. Results of this study follow those from the first three years of this study that were previously published. ${ }^{2}$ Those early results illustrated that marsh functions in the experimental wetlands diverged and then converged in concert with divergence and convergence of macrophyte development. After 6 years, some of those findings were validated while our conclusion on the time over which introduction of plant diversity has a measurable effect on ecosystem function is now determined to be longer than we originally thought. 


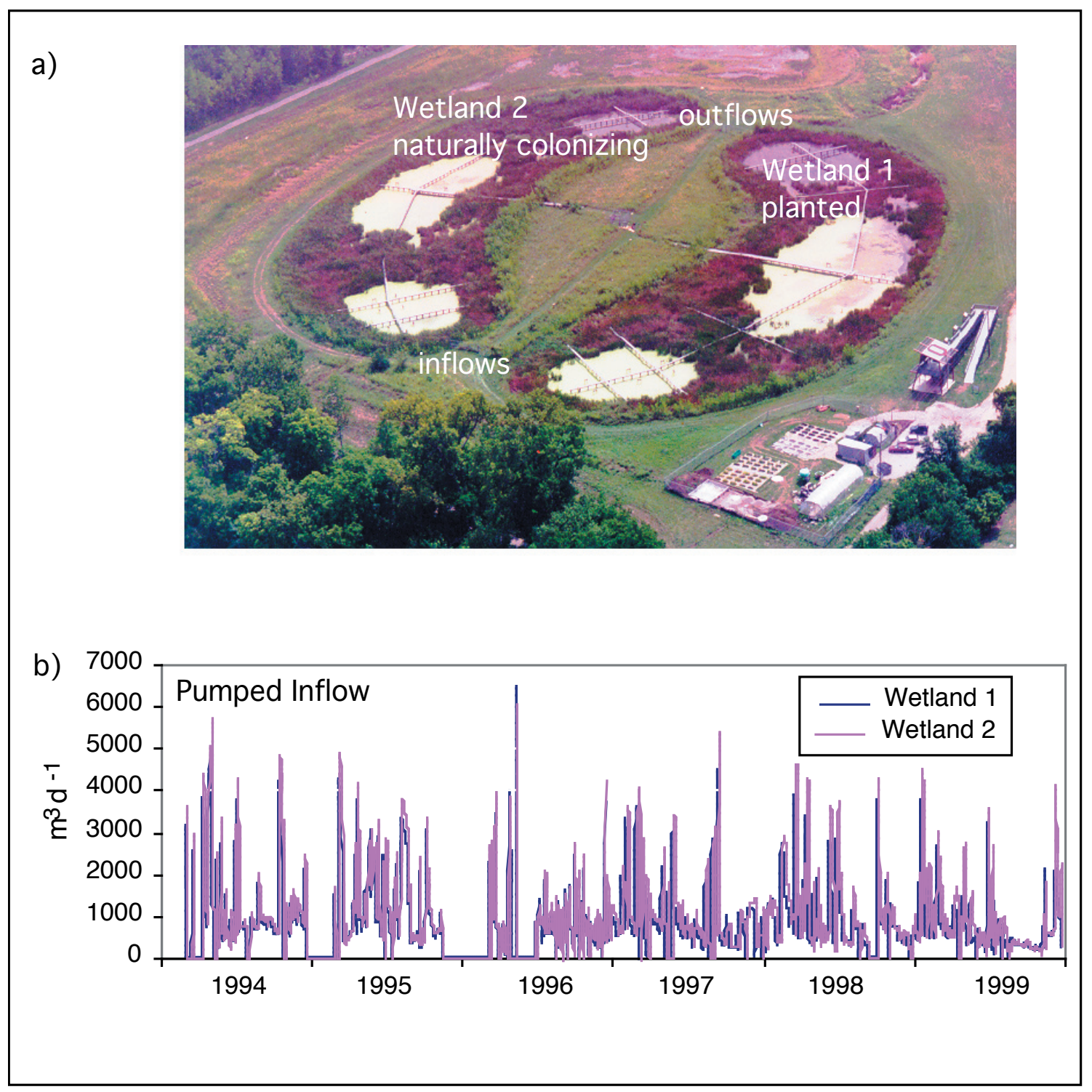

Figure 1. a) Paired 1-ha experimental wetlands at the Olentangy River Wetland Research Park at The Ohio State University (photo in August 1999). Planted wetland basin (W1) is on the right; basin planted by nature (W2) is on the left; b) pumped inflow to planted (W1) and naturally colonizing (W2) wetland basins for the 6 years described here. Water levels and water budgets were essentially identical over the 6-year period discussed here. 


\section{Methods}

\section{Site history}

Two 1-ha experimental wetlands and a river water delivery system were constructed in 1993-94 at The Olentangy River Wetland Research Park, a 10-ha site on the campus of The Ohio State University in Columbus (Fig. 1a). Over 2,400 plant propagules (mostly root stock and rhizomes) representing 13 species typical of Midwestern USA marshes were planted in one wetland (Wetland 1=W1) in May 1994. Wetland 2 (W2) remained unplanted. Both wetlands received the same amount and quality of pumped river water and both have had essentially identical hydroperiods for the entire six-year study period (Fig. 1b). Pumped river water generally flows into the wetlands continuously, day and night, except for planned drawdowns, and occasional short-term unscheduled pump failures. After start-up trials in 1994, a pumping protocol was developed that involves changing the pumping rate manually 2 or 3 times per week according to a formula that calls for more pumping when river discharge is high and less pumping when river flow is low. On an annual average, pumped inflow to each wetland has been $20-40 \mathrm{~m} / \mathrm{yr}$. Water depths in the major portions of the wetland are generally 20 to $40 \mathrm{~cm}$ in the shallow areas where most of the emergent macrophytes grow and 50 to $80 \mathrm{~cm}$ in the deepwater areas that were constructed in the wetland to allow over wintering of nekton and additional sediment storage. Five river flooding events occurred during the study period. During each of these floods, water from the river spilled into the wetlands in approximately equal amounts.

\section{Macrophyte community index}

Macrophyte coverage by dominant community is estimated each year from aerial color photography taken at the period of peak biomass (late August), coupled with ground truth surveys. Ground surveys involved mapping plants along 500 m of 7 transects (shown in Fig. 1a) in each wetland. Transect permanent walkways are about $1.5 \mathrm{~m}$ above the wetland soil, thus giving a good perspective even with $3 \mathrm{~m}$-tall plants. A $10 \mathrm{~m} \times 10 \mathrm{~m}$ grid system marked with permanent numbered white poles is used to identify the location of plant communities in each wetland. Maps for each year are normalized to the same size basin map utilizing geographic information system software.

We developed a macrophyte Community Diversity Index (CDI) to quantify the diversity in the wetland basins. The index used relative areas of macrophyte community cover from the maps derived above and the mathematics of the Shannon-Weaver diversity index, with area of each community instead of number of individuals of each species used. It is expressed as:

$$
\mathrm{CDI}=-\sum_{\mathrm{i}=1}^{\mathrm{N}} \mathrm{C}_{\mathrm{i}} \ln \left(\mathrm{C}_{\mathrm{i}}\right)
$$

where

$\mathrm{C}_{\mathrm{i}}=$ percent cover of wetland community "i" (0 to 1$)$

in the wetland basin

$\mathrm{N}=$ number of wetland communities

Overall, there were seven different communities identified by our combination of aerial photography and subsequent ground surveys during the 6-year study. They were named for the dominant species in community:

* Schoenoplectus tabernaemontani,

* Typha spp.,

* Scirpus fluviatilis,

* Nelumbo lutea,

* Sparganium eurycarpum,

* Spartina pectinata, and

* open water/submersed aquatics.

\section{Field indicators}

Aboveground biomass during August was used as an estimate of aboveground net primary productivity (ANPP). It was estimated directly beginning in 1997 by direct aboveground harvesting of sixteen $1-\mathrm{m}^{2}$ plots in each wetland along sampling boardwalks and from aerial photography and fewer sample plots before that. Algae are sampled several times each year at inflow, middle, and outflow areas in both wetlands with a plankton net tossed $5 \mathrm{~m}$ and retrieved with a cord. Samples representative of metaphyton such as attached and benthic algae are taken by hand. Algal species are identified by microscope at $100 \mathrm{x}$ and 400x and relative abundance of each genus is estimated. Daily dawn-dusk-dawn readings of dissolved oxygen from manually taken measurements at the outflows are used to estimate aquatic productivity of the water column. ${ }^{19}$ More than 60 such paired dawn-dusk samples were available each year. Benthic invertebrates are sampled in late October - early November annually with Hester-Dendy plates (11 $\mathrm{cm}^{2}$ ) placed at nine stations in each wetland. Sometimes this sampling has been supplemented with dip net collections and bottle collections. Invertebrates are sorted to lowest recognizable taxa and Shannon-Weaver diversity indices are estimated with these taxa counts. Taxa diversity measures with and without pollution-tolerant organisms (oligochaetes, tubificids, and chironomids) were used as relative indicators in the two wetlands of aquatic community diversity.

Manual sampling of water temperature, dissolved oxygen, $\mathrm{pH}$, conductivity, and redox has been done twice-per-day (dawn and dusk) with Hydrolab H20G or YSI 6000 water quality sondes at the inflow of the wetlands and outflows of both wetland basins. One-hundred $\mathrm{mL}$ samples are also taken dawn and dusk each day at the inflow and two outflows for turbidity analyses in the laboratory with a Hach ratio turbidimeter. In addition to the twice-per-day manual sampling, weekly water samples are taken at inflows and outflows of the wetlands for nutrients which were determined by standard methods.$^{20,21}$

Basins were observed for avian activity in the early years through exact walking paths by experienced observers several times during the year. Comparison of avian use of 
the basins in 1999 was made through frequent visits to the basins in spring. Bird presence is noted by both songs and sightings.

\section{Similarity index}

Basins were compared yearly by using 16 indicators, listed in Table 1 and described above, that represent the structure and function of the wetland ecosystems. We used one indicator of macrophyte function (aboveground net primary productivity), four indices of aquatic community development (two macroinvertebrate diversity indices, aquatic GPP, and algal species richness), six indicators of wetland biogeochemistry (outflow concentrations of $\mathrm{pH}$, conductivity, redox, turbidity, dissolved oxygen, and temperature), three indicators of nutrient retention (SRP, total $\mathrm{P}$, and nitrate-nitrogen retention), and two indicators of avian use (bird abundance and species richness) in each wetland basin. The non-parametric similarity of each basin was estimated with a similarity index (SI) calculated as:

$\mathrm{SI}=\left[\mathrm{I}_{\mathrm{S}} / \mathrm{I}\right] \times 100$

where

$\mathrm{SI}=$ similarity index

$\mathrm{I}_{\mathrm{S}}=$ number of similar functional indicators in a given year

$\mathrm{I}=$ total number of functional indicators $=16$

\section{Results}

\section{Macrophyte community diversity}

Emergent macrophyte communities developed in both wetlands to the point where almost all of the available shallow water area was vegetated by the end of the fourth growing season (Table 2). Vegetation appeared to converge by the third year with each basin dominated by Schoenoplectus tabernaemontani but with some presence of naturally colonizing Typha in each basin. Typha spp., a clonal dominant, was not planted but was seen in both wetlands approximately 3 months after the 1994 planting. In the first year of convergence, 1996, Typha actually had slightly greater cover in the planted W1 (Fig. 2a). By 1997 (fourth year) it began to develop at a more rapid rate in $\mathrm{W} 2$ and by 1999 it has increased to $56 \%$ in basin W2 while it remained only $9 \%$ cover of basin $\mathrm{W} 1$. At this point all shallow areas in W2 were almost completely dominated by Typha sp. Similar areas in W1 in 1999 were dominated by communities in the following order from most to least dominant :

Sparganium eurycarpum > Schoenoplectus tabernaemontani $>$ Typha sp. > Scirpus fluviatilis.

Macrophyte species richness increased dramatically in years 3 and 4 to almost 100 species in both basins (Fig. $2 b)$. Species richness proved not to be a useful metric for comparing the two basins. When the wetlands are viewed in terms of plant cover using our community diversity index (CDI), which includes indications of evenness of plant cover as well as number of dominant communities, a different conclusion about macrophyte community diversity is reached (Fig. 2c). The data show two years of basin divergence. The first year of divergence was in year 2 when W1, the planted basin, had $13 \%$ plant cover but W2 had no macrophyte development. The second macrophyte community divergence occurred in the sixth year (1999) when, after 3 years of similar plant cover in the two basins, different spatial community diversity developed. The CDI in W2 dropped as Typha formed close to a monoculture while it increased in W1 as a good balance among 5 communities developed, with 4 of those communities dominated by plants introduced in the planting (Fig. 2c; Table 2).

\section{Macrophyte productivity}

Productivity ranged from 657 to $729 \mathrm{~g} \mathrm{~m}^{-2} \mathrm{yr}^{-1}$ in W1 and 756 to $1127 \mathrm{~g} \mathrm{~m}^{-2} \mathrm{yr}^{-1}$ in W2. In the first year that macrophyte above-ground net primary productivity (ANPP) was measured by our standard techniques (1997; fourth year of the study) it was statistically similar in both basins (Fig. 3a). ANPP was statistically higher $(\alpha=0.05)$ in W2 in both year 5 (1998) and year 6 (1999) due to the dominance of the highly productive Typha that covered 43 and $56 \%$ of $\mathrm{W} 2$ in those two years respectively.

\section{Algal development}

Dense benthic and floating metaphyton were significant in both wetlands throughout the study because of more than adequate nutrient concentrations in the inflowing river water. In the first year, large metaphyton mats developed in both basins; these mats were composed of Hydrodictyon reticulatum (L) Lag. and Rhizoclonium spp. along with extensive epiphytes of several species of Chlorophyta and Chrysophyta. ${ }^{22}$ In the second year, the planted wetland(W1) carried an average of $80 \%$ of all of the genera identified while the unplanted wetland (W2) supported less (70\% of those genera). By the third year (1996), that statistic was $79 \%$ for $\mathrm{W} 1$ and $74 \%$ for $\mathrm{W} 2$, illustrating some convergence. The apparent increase in algal diversity in W2 in the third year correlated with the natural colonization of macrophyte cover.$^{2}$ Macrophytes may have increased habitats for the microphytes. By the fifth year (1998), the deepwater areas in the two wetlands started to become dominated by Lemna minor, causing dramatic decreases in metaphyton during some periods. Although there have been some differences in the two basins in 1998 and 1999, it appears that there has been general convergence of algal species since year 3 (1996).

Gross primary productivity (GPP) in the water column, as a functional measure of algae and submersed aquatic communities, was generally inversely related to macrophyte productivity (Fig. 3b). When productivity of macrophytes was different between the two wetland basins, as was the case in the second (1995) and fifth (1998) and sixth (1999) years, GPP in the water column compensated by being higher in the basin with lower macrophyte productivity. When there were 
Table 1. Indicators of ecosystem structure and function used to compare experimental 1-ha wetlands at Olentangy River Wetland Research Park, 1994-99.

I. macrophyte community function

1. net aboveground primary productivity

II. aquatic community development

2. algal species richness

3. aquatic metabolism

4. macroinvertebrate diversity

5. "clean water" species richness

III. biogeochemistry

6. temperature change

7. turbidity change

8. dissolved oxygen change

9. $\mathrm{pH}$ change

10. specific conductance change

11. redox change

IV. nutrient dynamics

12. total phosphorus change

13. soluble reactive phosphorus change

14. nitrate+nitrite change

V. Avian use

15. abundance

16. species richness macrophyte community organic production

water column diversity

water column organic production

benthic biodiversity

balance of $P$ and $R$

shading of water column

sedimentation/resuspension

oxidation/reduction

$\mathrm{CO}_{2}$ uptake/release in water

chemical precipitation/absorption

oxidation/reduction balance

phosphorus retention

phosphorus microbial uptake

denitrification/nitrogen retention

food source/habitat abundance

food source/habitat richness 


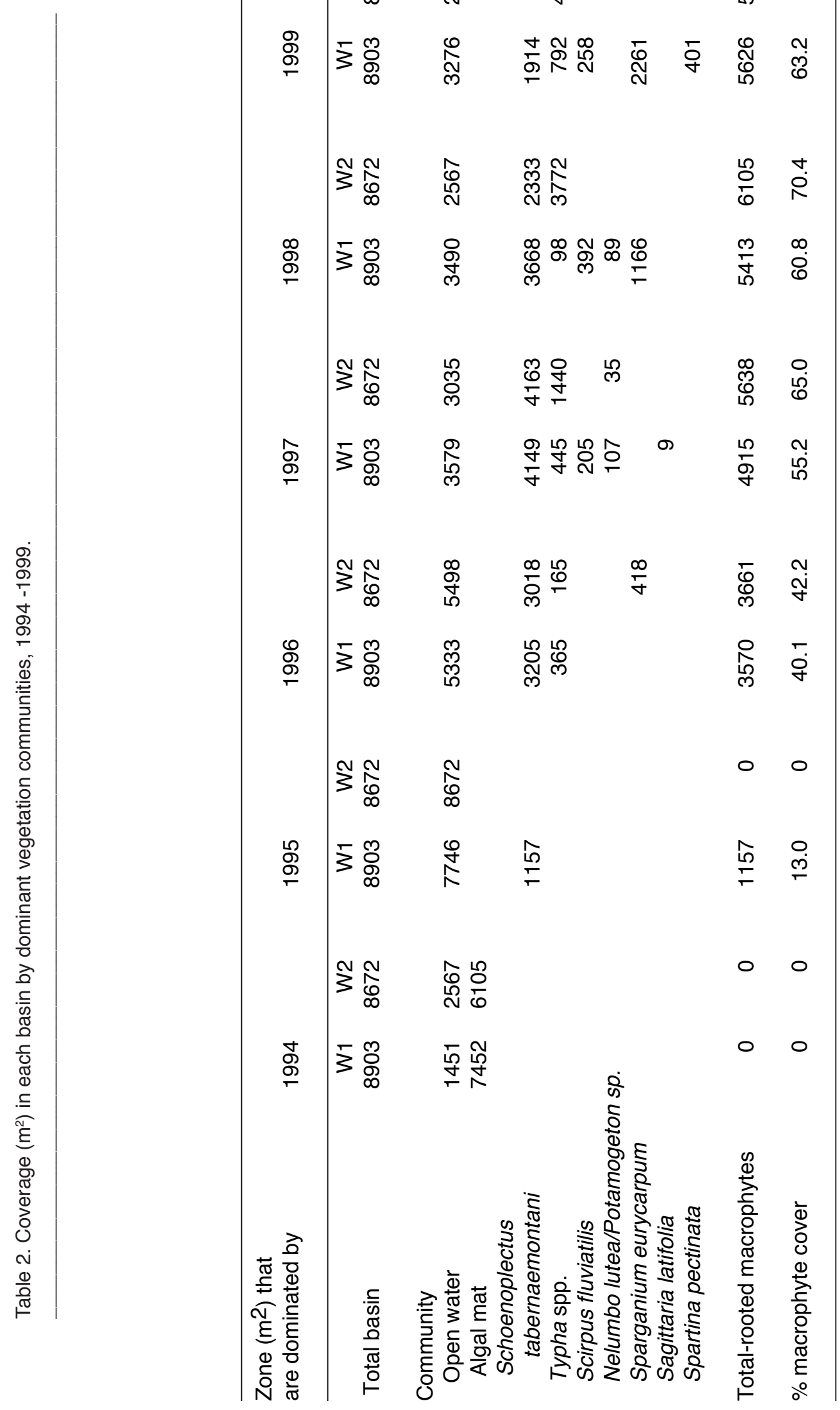




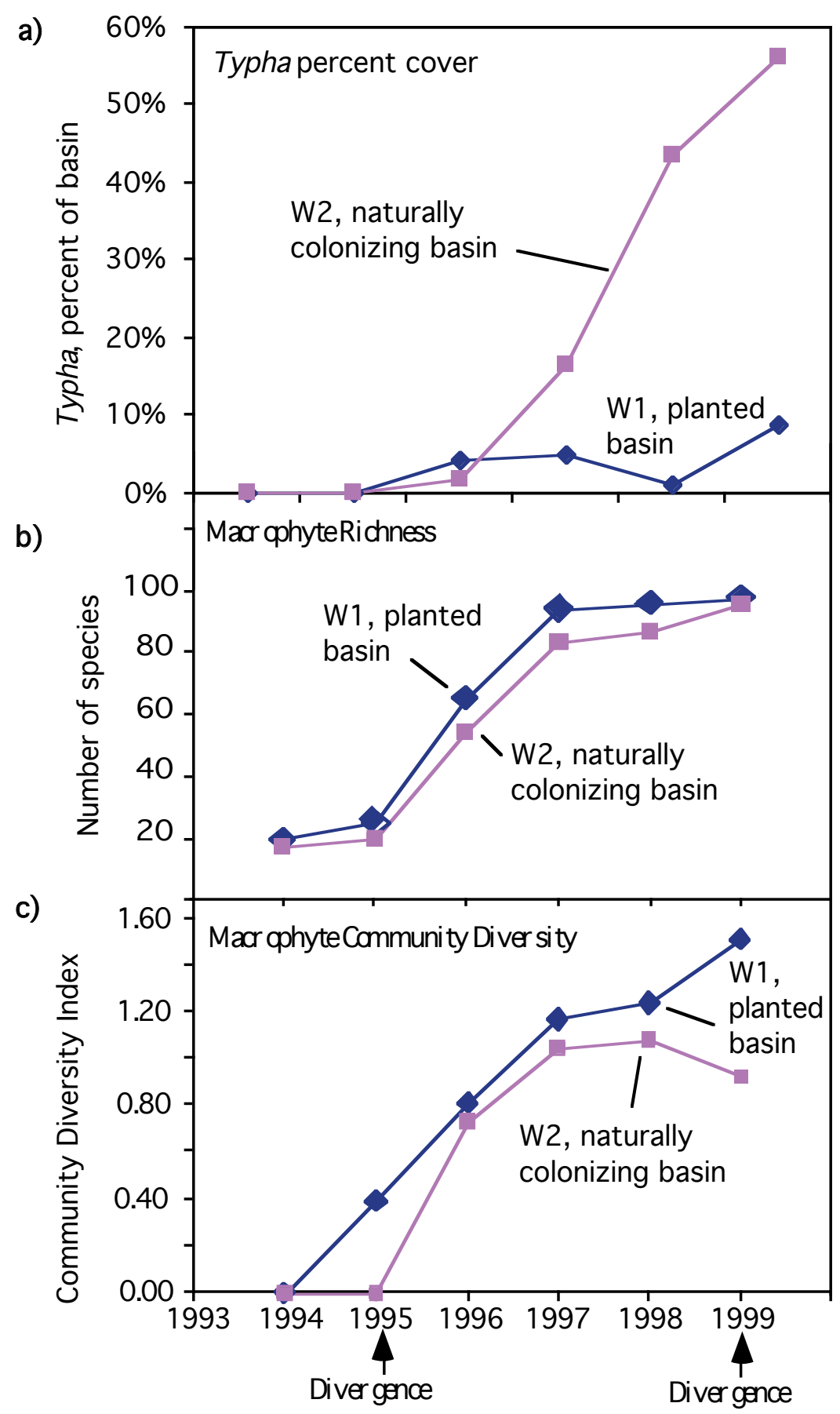

Figure 2. Indicators of macrophyte diversity in the two experimental wetlands, 1994-99: a) Percent of cover that is Typha spp.; b) macrophyte species richness; and c) macrophyte community diversity index (CDI). Note divergence of macrophyte community diversity in 1995 (year 2) and in 1999 (year 6). 
considerable macrophytes in the planted $\mathrm{W} 1$ but not in the unplanted wetland (W2) in the second year, water column GPP was higher in the unplanted wetland W2 by $38 \%$. The situation reversed in 1999 when statistically higher water column GPP occurred in the planted wetland (W1) than in the naturally colonizing wetland (W2), consistent with the greater macrophyte biomass cover in W2.

\section{Macroinvertebrate Diversity}

Macroinvertebrate taxa diversity remained statistically similar from 1996 through 1998 when plant communities were well developed but similar in both wetlands (Table 3). Taxa diversity diverged in 1999 when Typha-dominated W2 had a statistically higher benthic invertebrate diversity. Except for the first two years of wetland development, clean water species richness and diversity (count and diversity of all taxa minus chironomids, oligochaetes, and tubificids) were generally similar in both wetlands (Table 3 ).

\section{Water chemistry}

Water chemistry changes as the water flowed through the wetlands showed several differences between the two wetlands in certain years and for certain parameters (Fig. 4). In the sixth year, 7 of 9 parameters were different from inflow to outflow in each wetland $(\alpha=0.05)$ and the wetlands were different from one another $(\alpha=0.05)$ in 5 of 9 water quality parameters. Changes also occurred from year to year as macrophyte cover developed and began to influence water quality. For example, temperature increased through the wetlands on average in each of the first 5 years, but the increase was less each year (Fig. 4a). By the sixth year (1999), temperature actually decreased on average as water flowed through the wetlands and was also statistically different in the two basins after two years of convergence. Average dissolved oxygen (daily average of dawn and dusk readings; Fig. 4b) was initially different in the two basins (1994 and 1995) and increased by 30 to $45 \%$ through W2, which did not have any macrophytes shading the water during this period. When macrophytes developed in the basins, as they did from 1995 in W1 and from 1996 in W2, dissolved oxygen increased by $25 \%$ or less. Dissolved oxygen increase was higher in the planted W1 in 1999 after 3 years of similarity. pH (Fig. 4c) was significantly different in the two wetlands during four of the six years. It increased more in the then-unvegetated W2 than in the planted W1 in the early years (1994 and 1995). This pattern reversed in later years when $\mathrm{W} 1$ had significantly higher $\mathrm{pH}$ than the naturally colonizing wetland $\mathrm{W} 2$ in years 5 and 6 (1998 and 1999). Conductivity changes (Fig. 4d) were significantly different between the two wetlands during the second year and in the final 3 years. Conductivity decreased more in the then-unvegetated W2 in 1995. Then the pattern switched, with conductivity decreasing more in the planted W1 than in W2 in 1997 through 1999. The pattern also showed that, except for the first year, there was generally less change in conductivity through the wetlands with each succeeding each year as macrophyte vegetation developed. Turbidity, as a measure of suspended materials that include allochthonous clay and silt particles and autochthonous algal cells, decreased through the wetland every year (Fig. 4e). Changes through the two wetlands were different in the second (1995) and sixth (1999) years, the same two years in which the macrophyte diversity (CDI) diverged. In 1995 turbidity decreased more in the planted W1 than in the stillunvegetated W2. In 1999, turbidity also decreased more in the diverse wetland $\mathrm{W} 1$ than in the Typha monoculture W2. Redox potential (Fig. 4f) in the outflow water has not differed much in the two wetlands except early in the study. It also appears that redox potential is decreasing more each year in both wetlands' outflows. In 1997 redox potential was essentially unchanged from inflow to outflow. In 1999 it decreased on average between 6 and 7 percent.

\section{Nutrient retention}

Nutrient (phosphorus and nitrogen) reduction was consistent and significant in both wetlands throughout the six years for the three nutrient species analyzed (Fig. 5). Total phosphorus concentration annual reductions ranged from 18 to $73 \%$ per wetland and there appears to be a trend of less total phosphorus retention each year. Percent reduction of soluble reactive phosphorus (SRP) through the wetland basins has been higher (50 to $90 \%$ removal) and more consistent than that of total phosphorus . Percent reduction of nitrate+nitrite-nitrogen has remained consistent from year to year (generally between 20 and $50 \%$ reduction) in each wetland. Decreases from inflows to outflow have been significantly different for both wetlands and all years $(\alpha=$ $0.05)$. There were few statistically significant differences in nutrient retention between the wetlands over the sixyear study with only two differences out of a possible 18 parameter-years.

\section{Avian use}

Atotal of 150 bird species were identified at the Olentangy River Wetland Research Park from 1992-99 with a 20\% increase in species richness in the first year after wetland construction, another $8 \%$ increase during the second year, and an additional $5 \%$ increase in the third year. The creation of the wetlands resulted in the addition of about 35 wetlandspecific bird species to the site. Because of the proximity of the two wetlands, it has been generally difficult to compare avian use of the two wetlands. Nevertheless, surveys in the second year and reported previously did find that the planted W1 consistently supported a greater number of species (nesting and migratory) and more individuals than did the unplanted W2. ${ }^{2}$ Two species in particular, the sora (Porzana carolina) and marsh wren (Cistothorus palustris), were found exclusively in the planted wetland in the second year. By the third year, with the development of vegetation cover in the unplanted W2, differential bird use between the two wetlands declined and similar numbers and richness of species were found in each. With the development of different macrophyte communities in 1999 in the two 
wetlands, differences in bird use between the basins were observed (Fig. 6). There were significantly greater numbers of red-winged blackbirds (Agelaius phoeniceus) in W2 and significantly greater numbers of song sparrows (Melospiza melodia) in W1. Red-winged blackbirds have a great affinity for Typha while song sparrows favor the less dense vegetation in wetland $\mathrm{W} 1$.

\section{Basin similarity}

According to our community diversity index (CDI) and similarity index (SI) of wetland structure and function, there were two years out of six where the two wetlands diverged (Table 4; Fig. 7). In the second year (1995) after wetland construction, substantial macrophyte cover developed only in the planted wetland W1 as expected and none was present in W2; therefore the CDI index was different in the two wetlands (it was 0.0 for the unplanted wetland). Only $13 \%$ of the ecosystem indicators were similar $(\mathrm{SI}=13 \%)$. In years 3,4 , and 5, the macrophyte CDI was similar between the two wetlands and the ecosystem similarity converged to 75 - 87\%. Typha invasion into the unplanted wetland in the sixth year (1999) caused a second divergence in the CDI between the two basins (Fig. 3c) and wetland function diverged a second time (Fig. 7). During this year the similarity of the two wetlands dropped to $44 \%$.

The similarity index between the two wetlands for each year is plotted versus the difference in the community diversity index (CDI) between the basins for the same year (Fig. 8). The regression $\left(r^{2}=0.53\right)$ suggests that when the two basins were different in community diversity (as in 1995 and 1999) the two wetlands were dissimilar in structure and function ( $\mathrm{SI}=13-43 \%)$. When the basins were similar in community diversity, the two basins were similar in structure and function (SI $=70-88 \%$ ).

\section{Discussion}

\section{Community diversity and ecosystem function}

Our study suggests that structure and function are related to macrophyte community diversity in wetlands. In years when macrophyte community diversity was similar between our two wetlands, ecosystem indicators were also similar. When wetlands had different macrophyte community diversity, structure and function were different. Our macrophyte community diversity index (CDI) is not a traditional species diversity of small managed plots but rather is a measure of the spatial diversity that can be seen from good aerial photography. It includes both the richness and evenness of communities patterns.

When aboveground net primary productivity is plotted versus CDI for 6 wetland-years, a negative relationship (Fig. 9). When the macrophyte community is diverse in terms of spatial patterns. While our study uses a measure of spatial community diversity (the diversity of pixels in a color map) and other studies count individual plants or stems, some comparison can be made between our general findings and those suggested by others on the relationship between productivity and diversity. Plot and small-scale terrestrial research often illustrates that plant diversity has a positive effect on primary productivity. While this may hold true for managed diversity of plants on small plots, our results show exactly the opposite for large-scale wetlands. Higher diversity on a community scale (that is, how many different macrophyte communities are present and how even their distribution is) not only does not enhance productivity, our study suggests that it reduces it. This tempers the universality of conclusions suggested by studies in grasslands ${ }^{27,28}$ and more recently for mesocosm wetlands ${ }^{6}$ that diversity enhances productivity. These studies were carried out on smaller scales than ours and were also subject to some manipulation to maintain certain diversities. ${ }^{23,24}$

There was no significant relationship seen in our study between community diversity index (CDI) and gross primary productivity of algal communities $\left(\mathrm{r}^{2}=0.004\right)$ or nutrient and sediment retention (phosphorus: $\mathrm{r}^{2}=0.017$; nitrates: $\mathrm{r}^{2}$ $=0.004$; turbidity: $r^{2}=0.05$ ). This last lack of a significant relationship is in direct conflict with the conclusion by Engelhardt and Ritchie ${ }^{6}$ that "higher vascular plant richness in wetlands may potentially yield up to $25 \%$ more algal biomass.... and retaining (sic) up to $30 \%$ more potentially polluting nutrients, such as P." While these conclusions may be applicable to small-scale experiments they were not supported by our full-scale wetland ecosystem study.

\section{Productivity as the independent variable}

We suspect that asking what the effect is of diversity on productivity may be the wrong question to ask, as ultimately physical and chemical factors affect productivity, which in turn often determine biodiversity which feedbacks and affects the physics and chemistry. If we turn the cause and effect around by rotating Fig. 9 ninety degrees, we have illustrated what is already fairly well established in the wetland literature ${ }^{25-27}$ that species richness and diversity in freshwater marshes and lakes are inversely related to biomass and productivity. Productivity in turn is related to factors such as nutrients, sunlight, and flooding. When primary productivity is viewed in this way as the independent variable, then several ecosystem functions which do not correlate well with macrophyte community diversity, correlate much better with marsh net primary productivity. Total phosphorus, nitrate-nitrogen, and to a lesser degree, turbidity reductions are positively related to ANPP (Fig. 10). Although long suspected, there has been no study to our knowledge that has confirmed this relationship at a full-ecosystem scale. Tanner ${ }^{28}$ found a relationship between biomass (productivity) and nitrogen uptake similar to the one we did between ANPP and nitrogen retention. His New Zealand study involved gravel-bed mesocosms fed by high-concentration dairy wastes. Therefore, nitrogen concentrations were substantially greater in his study than ours. Experiments in Norway ${ }^{29}$ involving 4 small wetlands showed that suspended sediment retention increased with 


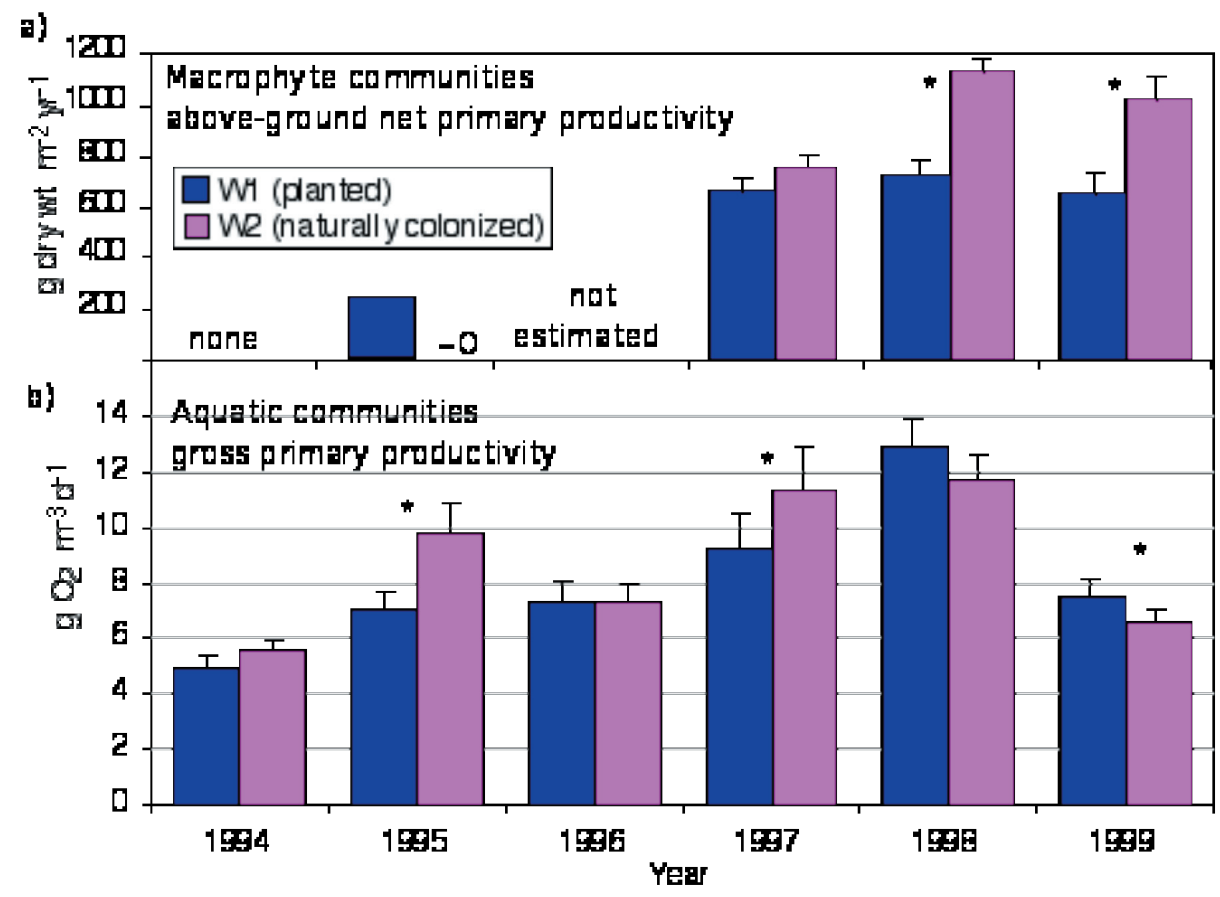

Figure 3. a) Macrophyte net aboveground primary productivity (NAPP) in grams dry weight and b) aquatic community gross primary productivity (GPP) in grams $\mathrm{O}_{2}$ of two experimental wetlands. Asterisk ( $\left(^{*}\right)$ indicates significant difference between wetlands $(\alpha=0.05)$. Macrophyte NAPP was not estimated during the first 3 years by harvesting because of the feared impact that would have on the experiment when vegetation was just starting. Vegetation was different in 1995 because there were essentially no macrophytes in W2 in that year while the planted macrophytes covered $13 \%$ of $\mathrm{W} 1$.

Table 3. Benthic invertebrate diversity in two experimental wetlands, 1994-1999

\begin{tabular}{lllll}
\hline Year & \multicolumn{2}{l}{ Total count diversity index } & \multicolumn{2}{l}{ "Clean water" diversity index } \\
\hline & W1 & W2 & W1 & W2 \\
1994 (planting) & 0.63 & 0.69 & 0.45 & 0.60 \\
1995 (divergence) & 0.50 & 0.62 & 0.98 & 0.51 \\
1996 (convergence) & 0.88 & 0.83 & 0.88 & 0.86 \\
1997 (convergence) & $1.34 \pm 0.02$ & $1.41 \pm 0.18$ & $1.23 \pm 0.28$ & $0.96 \pm 0.17$ \\
1998 (convergence) & $0.58 \pm 0.43$ & $0.82 \pm 0.56$ & $0.58 \pm 0.43$ & $0.73 \pm 0.45$ \\
1999 (divergence) & $0.63 \pm 0.05^{*}$ & $0.91 \pm 0.12 *$ & $0.49 \pm 0.13$ & $0.61 \pm 0.17$ \\
\hline
\end{tabular}

Indices are Shannon-Weaver index

$\mathrm{W} 1$ = planted wetland; $\mathrm{W} 2$ = natually colonizing wetland

"Clean water" = all taxa execpt chironomids, oligochaetes, and tubificids

*Significant differences $(\alpha=0.10)$ between wetlands from last 3 years for paired

samples. Earlier years' data indicate overall diversity indices for entire wetland basin. 

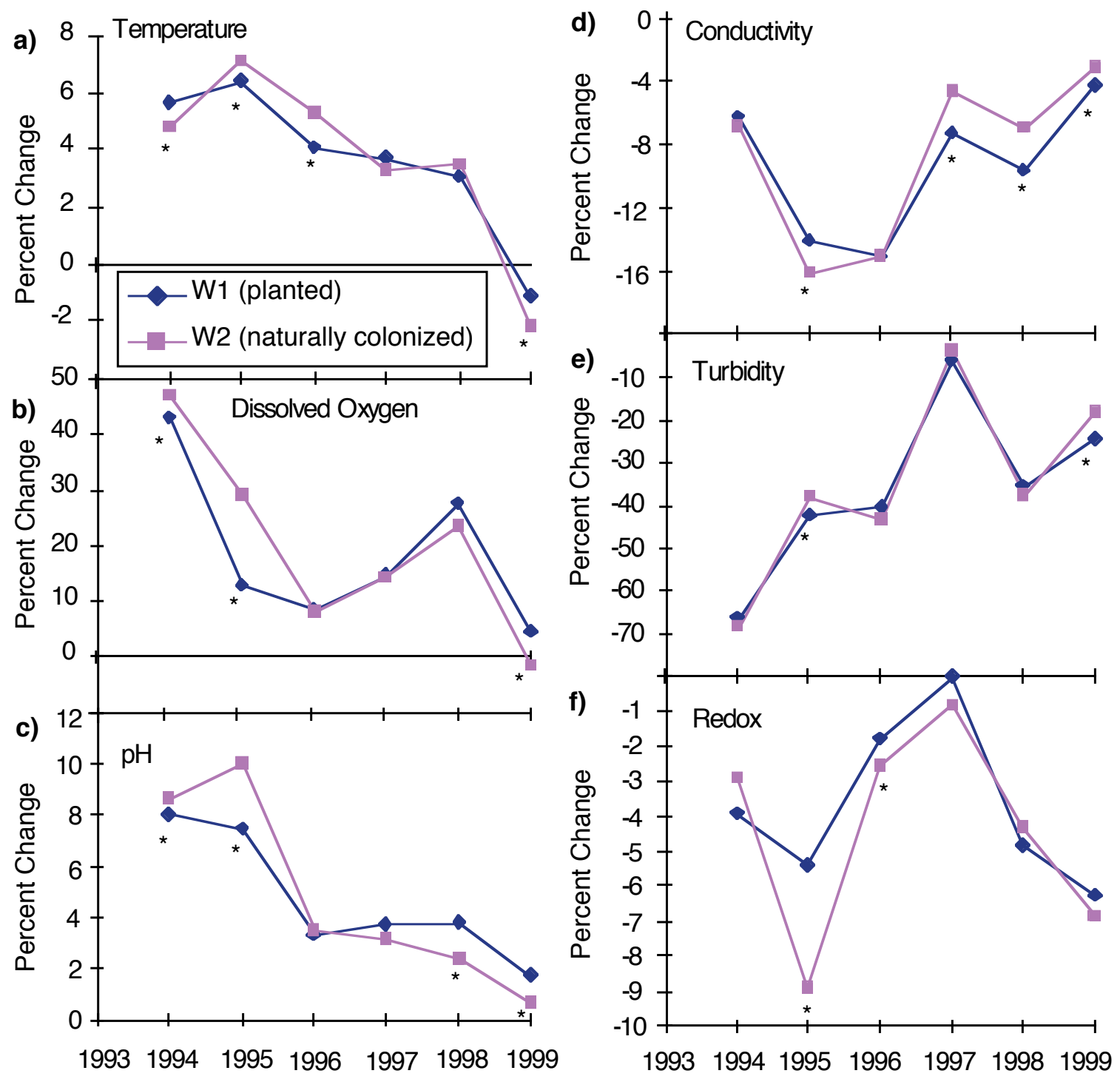

Figure 4. Water quality changes through experimental wetlands for 1994-99: a) temperature; b) dissolved oxygen; c) $\mathrm{pH}$; d) conductivity; e) turbidity; f) redox potential. Data points indicate overall percent change from inflow to outflow of averages of all inflow and outflow concentrations during that year. Each data point represents hundreds of samples per year. Asterisk $\left(^{*}\right)$ indicates significant difference between the wetlands as determined by t-test comparing outflow concentrations $(\alpha=0.05)$. 


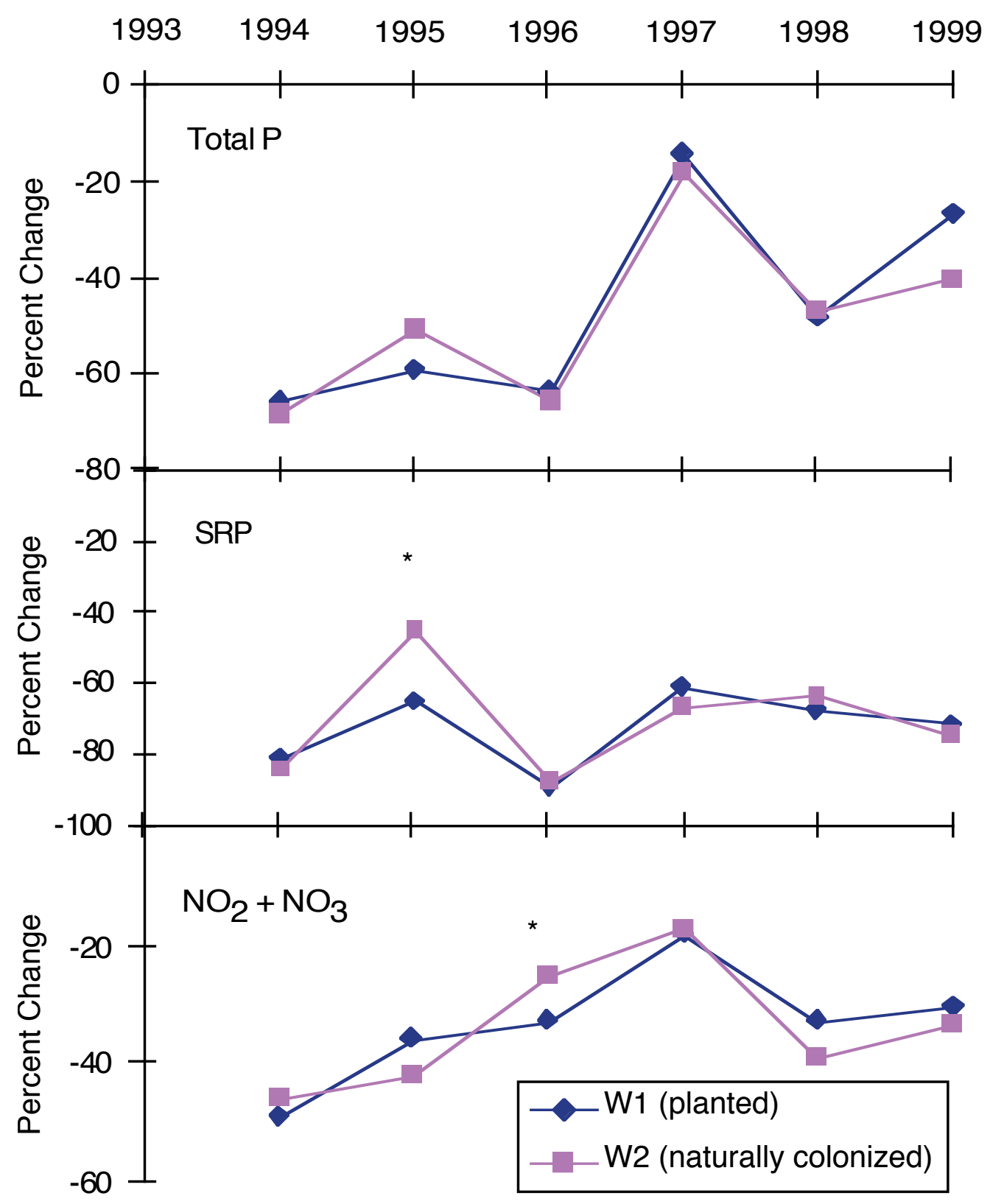

Figure 5. Nutrient retention in the two experimental wetlands for 1994-99: a) total phosphorus (Total P); b) soluble reactive phosphorus (SRP), and c) nitrite + nitrate nitrogen $\left(\mathrm{NO}_{2}+\mathrm{NO}_{3}\right)$. Data points indicate overall percent change from inflow to outflow of averages of all inflow and outflow concentrations. Each data point represents overall results of weekly readings over a year. Asterisk $\left(^{*}\right)$ indicates significant difference between the wetlands as determined by t-test comparing outflows $(\alpha=0.05)$. 


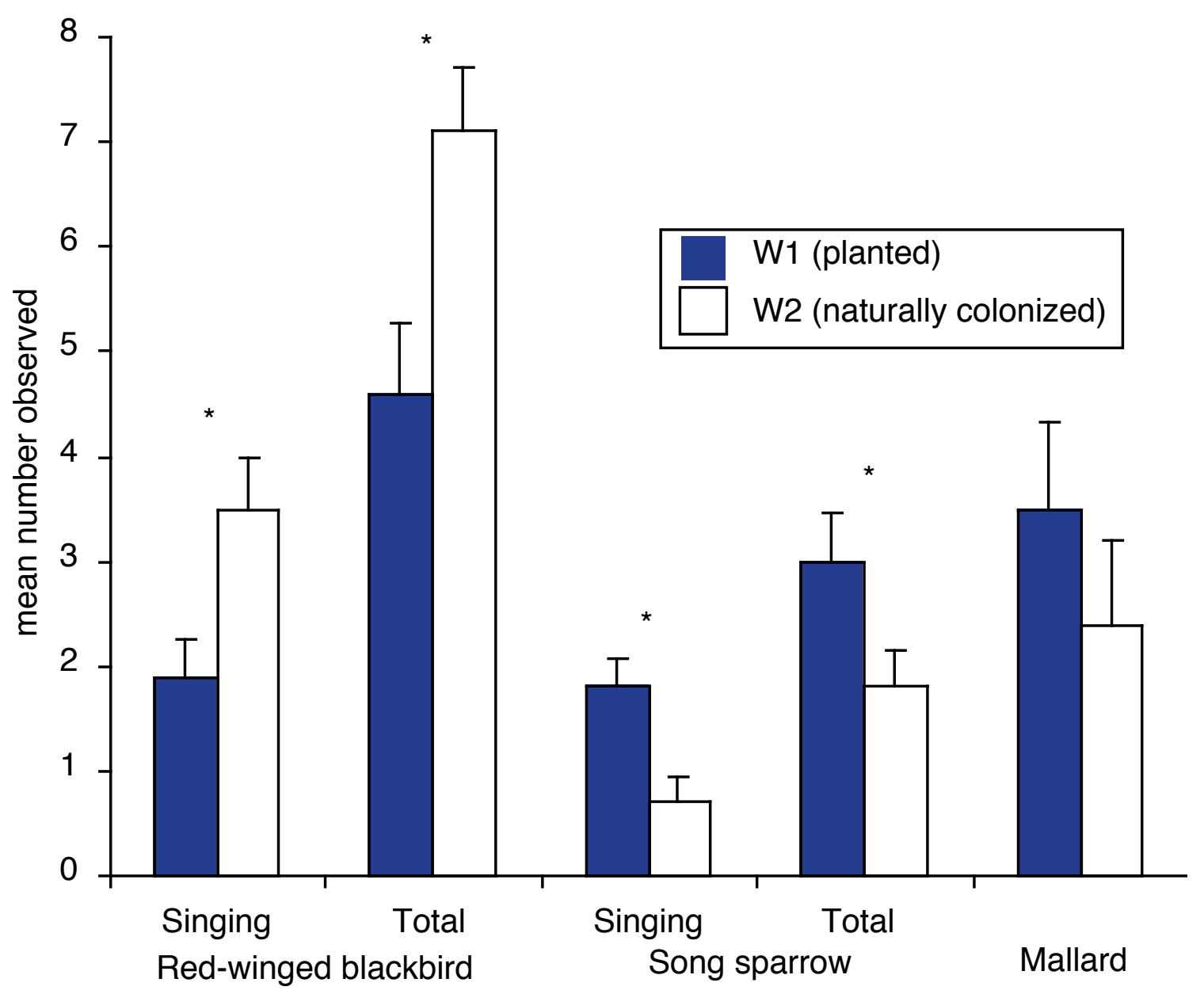

Figure 6. Bird observations comparing the two experimental wetlands in 1999. Asterisk $\left(^{*}\right)$ indicates significant difference between wetlands $(\alpha=0.05)$. 
greater vegetation cover, not so much because of any increase in sedimentation but because of a reduction in resuspension. Factors such as this are a more likely explanation for the Fig. 10 patterns than any direct uptake by the macrophytes.

\section{Diversity at different levels}

It is often assumed that if one trophic level of an ecosystem is diverse, that diversity will "spill over" to other parts of the ecosystem. This is a structure affecting structure argument and is partially the theory of consumer control of species diversity. ${ }^{30}$ The effect of macrophyte community diversity on benthic invertebrate diversity was compared for 1997-99 (3 wetland-years; Fig. 11) in the same fashion as the macrophyte comparison above. There was a weaker inverse relationship $\left(r^{2}=0.23\right)$ than that for the effect of macrophyte productivity on invertebrate diversity $\left(\mathrm{r}^{2}=\right.$ 0.43 ). Macrophyte community diversity does not appear to necessarily increase benthic diversity; in fact our data suggest that in some cases it reduced it.

\section{Aquatic consumers}

Aquatic consumers were sampled in the wetlands immediately after the year 6 divergence in macrophyte community diversity. There were more Rana catesbeiana (bullfrog tadpoles), Nerodia sipedon (northern water snakes) and Lepomis cyanellus (green sunfish) in the naturally colonizing wetland (W2) than in the planted wetland (W1) in the early 2000 sampling (Table 5). The greater abundance of tadpoles (which consume detritus and small insects) and snakes (which consume tadpoles) suggests a more powerful detrital food chain in W2 in early 2000 that is supported by the macrophyte net primary productivity that was almost 50\% higher there in 1999 than in W1. Green sunfish, a species common in wetlands because of its tolerance for warm summer temperatures, may also have been more abundant in W2 because of slightly cooler temperatures (water temperature was significantly cooler in W2 in 1999) caused by the higher macrophyte productivity which, in turn, provides more shade of the water. Greater macrophyte productivity also provides more locations for hiding from predators, including wading birds. The comparison between the wetland basins on fish populations should be made with caution as mark and recapture studies later in $2000^{31}$ showed significantly higher fish populations in $\mathrm{W} 1$ after vegetation in both wetlands was lost by a muskrat eatout.

\section{Replication and experimental scale}

Whole ecosystem studies, such as the one being conducted here, can provide useful comparisons of ecosystem functions when performed over a long period, even when replication is not possible due to the large size of these systems. We believed that 1 ha was of sufficient size to provide development of all potential ecosystem engineers including ducks, geese, frogs, snakes, and muskrats. C. Korner (conference communication) has made the case for more understanding and acceptance of large-scale experiments and observations in the literature, if for no other reason than that they are a necessary check on theories being published from smaller-scale studies chosen primarily because of elegant replications and statistics. Experiments at small scales allow us to have confidence in the ecological function of smallscale systems. We consider the conclusions of research such as those by Engelhardt and Ritchie's wading pool study ${ }^{6}$ on wetland macrophyte richness effects on wetland function as a major overreach given the limitations of small experiments representing full-scale ecosystem function. Using the appropriate experimental scale for extrapolating to the scale of ecosystem function is essential. ${ }^{32}$ The large size of the experimental ecosystems and the long period of the study compensates to some extent for the lack of replication. The insights of diversity and ecosystem function would not have manifested themselves in a short-time, small-scale experiment. Many of our findings from this large-scale experiment illustrate that cause and effect on the role of diversity and function may be the reversed of what is postulated in many previous studies.

Carpenter et al. ${ }^{18}$ suggest that rather than having an unreplicated experiment, one could actually have two or more similar ecosystems, each with different management or experimental schemes. In our case, we have two large wetland basins, each different means of plant propagule introduction - one by humans and nature and the other by nature. So in effect there is not a control where propagules are weeded or otherwise prevented from entering the wetlands. When one wetland became dominated by Typh $a$ and the other was not, we were in a good position to see the effects of Typha invasions and natural reduction in plant diversity. We believe that use of many physical, chemical, and biological indicators gives strength to our arguments that the basins are similar or dissimilar in any given year.

Specific to this wetland experiment, $\mathrm{we}^{33}$ compared one of the full-scale 1-ha wetlands with ten 1- $\mathrm{m}^{2}$ mesocosms in similar hydrologic conditions. While the mesocosm results had statistical rigor because of replication, they had so many scale effects and ecosystem simplifications as to prevent conclusions from being extended to large-scale wetlands without verification with full-scale wetlands. Mesocosmscale wetlands could not duplicate hydrodynamic features and lacked important aspects of full-scale wetlands such as wind mixing. Also, mesocosm studies of wetlands do not include proportional scales of ducks, geese, muskrats, beavers, and wading birds, all of which can be important "ecosystem engineers" of wetland function. ${ }^{26,34-35}$

We believe that our 1-ha wetlands, with the large area for all processes to manifest themselves in time and space, are inherently less variable and thus require far fewer replications. As suggested by Carpenter et al. ${ }^{18}$ we believe that there is no optimal scale for ecosystem experiments. But if we desire a system that equally can grow macrophytes, algae and invertebrates in the water column, and at the same time allow for a complete food web including ducks, wading birds, muskrats, and other important parts of any natural wetland, an experiment at 1-ha scale is much more likely to yield true ecosystem functions than would hundreds of 


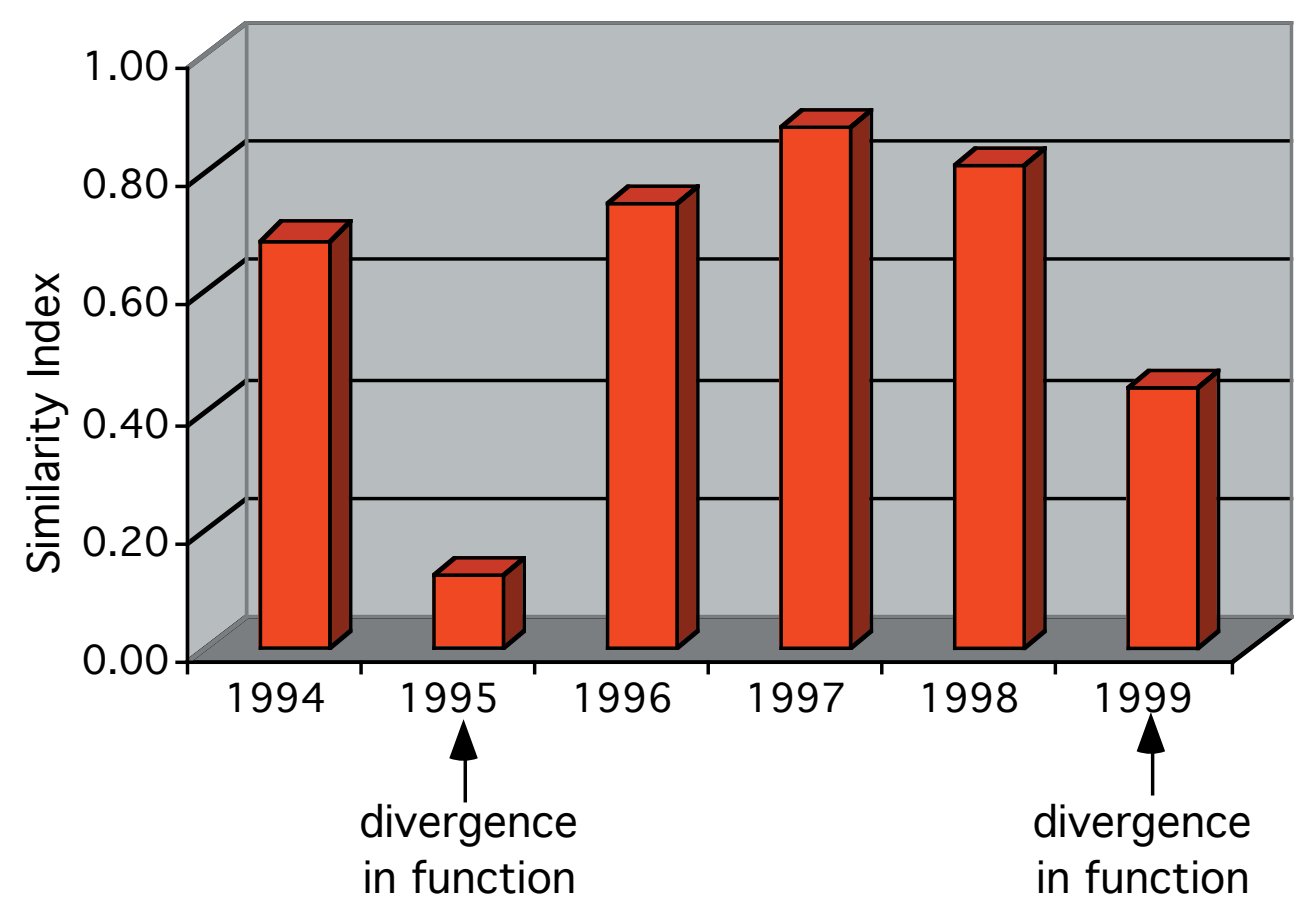

Figure 7. Indicators or similarity between two experimental wetland basins, 1994-99.

Table 4. Summary of 16 indices comparing Wetland 1 (W1) and Wetland 2 (W2) for 6 years, 1994-99

$1994 \quad 1995 \quad 1996 \quad 1997 \quad 1998 \quad 1999$

Macrophyte Diversity, CDI

I. Macrophyte Community Function NAPP

II. Aquatic Community Development Algal species richness

Aquatic metabolism

Benthic invertebrate diversity

Clean Water species richness

III. Biogeochemistry

Temperature

Turbidity

Dissolved Oxygen

$\mathrm{pH}$

conductivity

redox

IV. Nutrient Dynamics

Total P

SRP

$\mathrm{NO}_{3}+\mathrm{NO}_{2}$

V. Avian Use

Bird abundance

Bird species richness

Similarity Index, \%
$\mathrm{W} 1=\mathrm{W} 2 \mathrm{~W} 1>\mathrm{W} 2 \mathrm{~W} 1=\mathrm{W} 2 \mathrm{~W} 1=\mathrm{W} 2 \mathrm{~W} 1=\mathrm{W} 2 \mathrm{~W} 1>\mathrm{W} 2$

$\mathrm{W} 1=\mathrm{W} 2 \mathrm{~W} 1>\mathrm{W} 2 \mathrm{~W} 1=\mathrm{W} 2 \mathrm{~W} 1=\mathrm{W} 2 \mathrm{~W} 1<\mathrm{W} 2 \mathrm{~W} 1<\mathrm{W} 2$

$\mathrm{W} 1=\mathrm{W} 2 \mathrm{~W} 1>\mathrm{W} 2 \mathrm{~W} 1>\mathrm{W} 2 \mathrm{~W} 1=\mathrm{W} 2 \mathrm{~W} 1=\mathrm{W} 2 \mathrm{~W} 1=\mathrm{W} 2$ $\mathrm{W} 1=\mathrm{W} 2 \mathrm{~W} 1<\mathrm{W} 2 \mathrm{~W} 1=\mathrm{W} 2 \mathrm{~W} 1<\mathrm{W} 2 \mathrm{~W} 1=\mathrm{W} 2 \mathrm{~W} 1>\mathrm{W} 2$ $\mathrm{W} 1=\mathrm{W} 2 \mathrm{~W} 1<\mathrm{W} 2 \mathrm{~W} 1=\mathrm{W} 2 \mathrm{~W} 1=\mathrm{W} 2 \mathrm{~W} 1=\mathrm{W} 2 \mathrm{~W} 1<\mathrm{W} 2$ $\mathrm{W} 1<\mathrm{W} 2 \mathrm{~W} 1>\mathrm{W} 2 \mathrm{~W} 1=\mathrm{W} 2 \mathrm{~W} 1=\mathrm{W} 2 \mathrm{~W} 1=\mathrm{W} 2 \mathrm{~W} 1=\mathrm{W} 2$

$\mathrm{W} 1>\mathrm{W} 2 \mathrm{~W} 1<\mathrm{W} 2 \mathrm{~W} 1<\mathrm{W} 2 \mathrm{~W} 1=\mathrm{W} 2 \mathrm{~W} 1=\mathrm{W} 2 \mathrm{~W} 1>\mathrm{W} 2$ $\mathrm{W}_{1}=\mathrm{W} 2 \mathrm{~W} 1<\mathrm{W} 2 \mathrm{~W} 1=\mathrm{W} 2 \mathrm{~W} 1=\mathrm{W} 2 \mathrm{~W} 1=\mathrm{W} 2 \mathrm{~W} 1<\mathrm{W} 2$ $\mathrm{W}_{1}<\mathrm{W} 2 \mathrm{~W} 1<\mathrm{W} 2 \mathrm{~W} 1=\mathrm{W} 2 \mathrm{~W} 1=\mathrm{W} 2 \mathrm{~W} 1=\mathrm{W} 2 \mathrm{~W} 1>\mathrm{W} 2$ $W 1<W 2 W 1<W 2 \quad W 1=W 2 \quad W 1=W 2 \quad W 1>W 2 \quad W 1>W 2$ $W_{1}=W 2 \quad W 1>W 2 \quad W 1=W 2 \quad W 1>W 2 \quad W 1<W 2 \quad W 1<W 2$ $\mathrm{W} 1=\mathrm{W} 2 \mathrm{~W} 1>\mathrm{W} 2 \mathrm{~W} 1>\mathrm{W} 2 \mathrm{~W} 1=\mathrm{W} 2 \mathrm{~W} 1=\mathrm{W} 2 \mathrm{~W} 1=\mathrm{W} 2$

$\mathrm{W} 1<\mathrm{W} 2 \mathrm{~W} 1=\mathrm{W} 2 \mathrm{~W} 1=\mathrm{W} 2 \mathrm{~W} 1=\mathrm{W} 2 \mathrm{~W} 1=\mathrm{W} 2 \mathrm{~W} 1=\mathrm{W} 2$ $\mathrm{W} 1=\mathrm{W} 2 \mathrm{~W} 1>\mathrm{W} 2 \mathrm{~W} 1=\mathrm{W} 2 \mathrm{~W} 1=\mathrm{W} 2 \mathrm{~W} 1=\mathrm{W} 2 \mathrm{~W} 1=\mathrm{W} 2$ $\mathrm{W} 1=\mathrm{W} 2 \mathrm{~W} 1=\mathrm{W} 2 \mathrm{~W} 1>\mathrm{W} 2 \mathrm{~W} 1=\mathrm{W} 2 \mathrm{~W} 1=\mathrm{W} 2 \mathrm{~W} 1=\mathrm{W} 2$

$W_{1}=W_{2} W_{1}>W_{2} W_{1}=W_{2} W_{1}=W_{2} W_{1}=W_{2} W_{1}<W_{2}$ $\mathrm{W} 1=\mathrm{W} 2 \mathrm{~W} 1>\mathrm{W} 2 \mathrm{~W} 1=\mathrm{W} 2 \mathrm{~W} 1=\mathrm{W} 2 \mathrm{~W} 1=\mathrm{W} 2 \mathrm{~W} 1=\mathrm{W} 2$ $\begin{array}{llllll}69 & 13 & 75 & 87 & 81 & 44\end{array}$ 


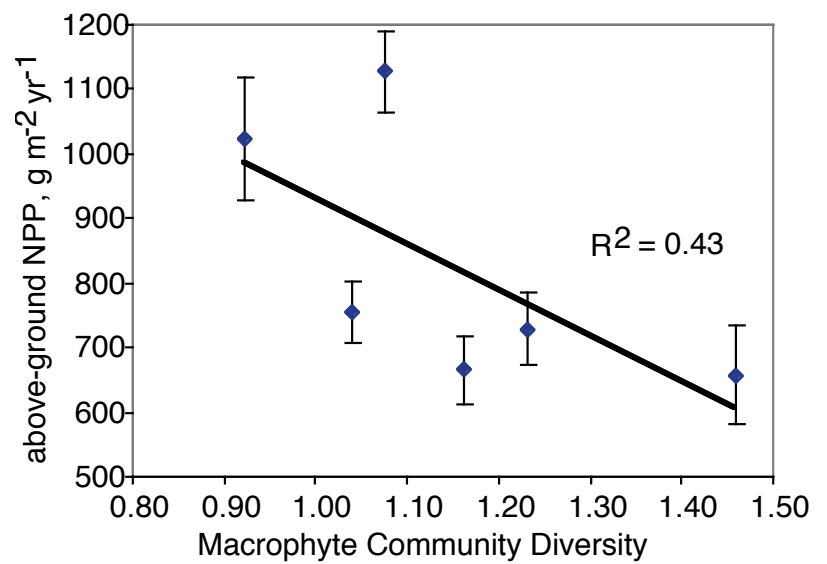

Figure 9. Relationship of aboveground net primary productivity (ANPP) to macrophyte community diversity index (CDI). Each data point is one of two 1-ha basins for years 1997-99.

$1-\mathrm{m}^{2}$ mesocosms. The use of easily measured multiple indicators allowed us to have more confidence in our relative comparison of these large-scale experimental units than if we relied on only a few indices.

\section{Acknowledgements}

We were assisted by many others in this multi-year study including Changwoo Ahn, Virginie Bouchard, Charles Boucher, Randy Bruins, Lesley Carmichael, Melanie Ford, Scott Frazier, Amiei Gifford, Sarah Harter, Cheri Higgins, Megan Hunter, Anne Johnson, David L. Johnson, Sharon Johnson, John Kantz, Katie Kleber, Michael Liptak, Kathy Metzker, Tony Minamyer, Holly Montgomery, Robert Nairn, Uygar Özesmi, Jeff Pearcy, Doug Spieles, Lisa Svengsouk, Rachael Thiet, Paul Weihe, and Renée Wilson. Also appreciated are a number of other students and volunteers who helped with the two-per-day and weekly sampling and laboratory work. This research was made possible by funding from Mid-American Waste Systems, Inc. Ohio Agricultural Research and Development Center, and several other private and public sources. Olentangy River Wetland Research Park Publication Number 2004-05.

\section{References}

1. Mitsch, W.J., and Wilson, R.F., Improving the success of wetland creation and restoration with know-how, time, and self-design, Ecol. Appl., 6: 77-83, 1996.

2. Mitsch, W.J. et al., Creating and restoring wetlands: A whole-ecosystem experiment in self-design. BioScience, 48: 1019-1030, 1998.

3. Mitsch, W.J. et al., To plant or not to plant-response. BioScience, 50: 188-191, 2000.

4. Streever, B. and Zedler, J.B., To plant or not to plant. BioScience, 50: 188-191, 2000.

5. National Research Council. Compensating for

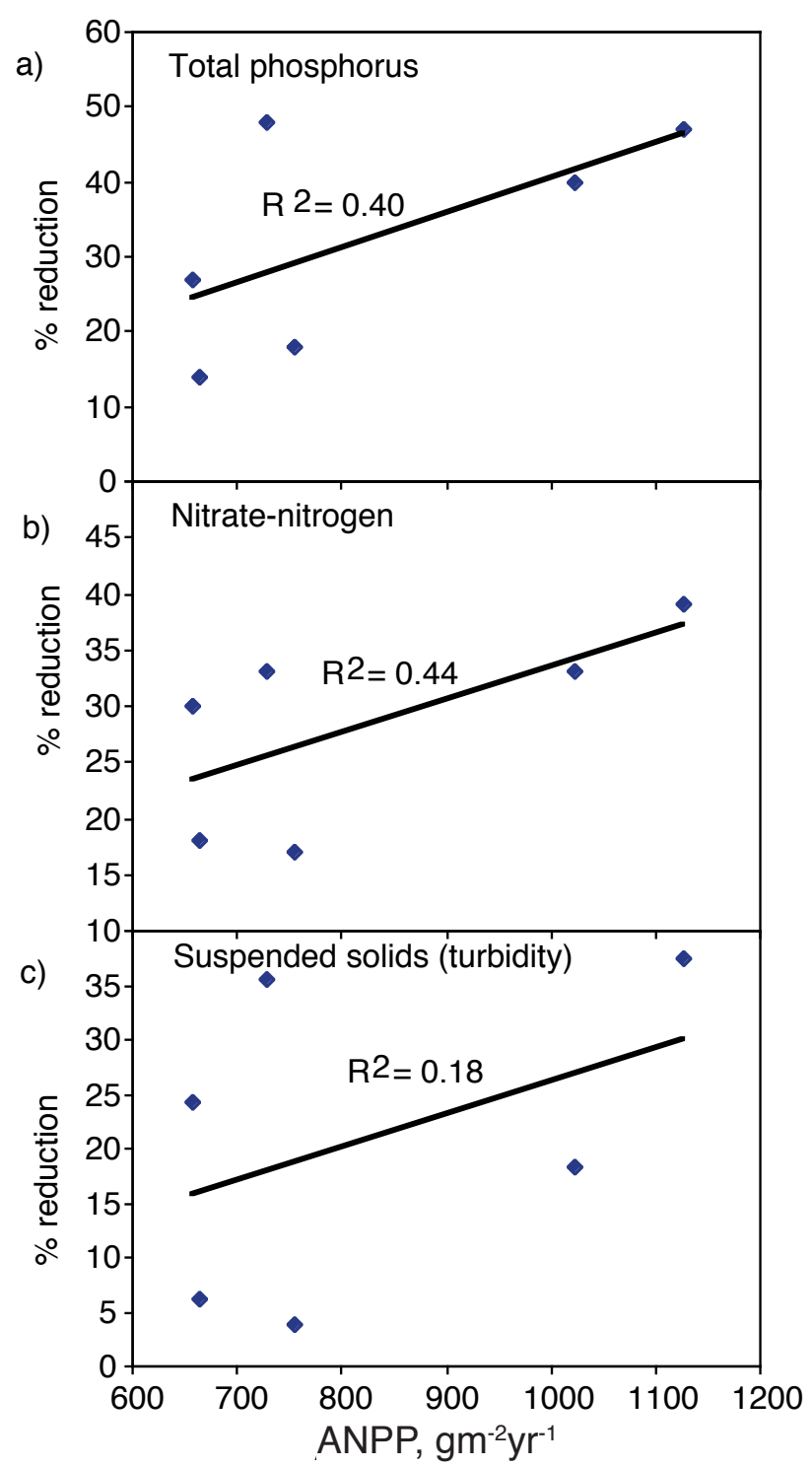

Figure 10. Relationship between nutrient reductions for a) total phosphorus, b) nitrate-nitrogen, and c) suspended solids (measured as turbidity) as a function of aboveground net primary productivity (ANPP) of macrophytes.

wetland losses under the Clean Water Act. Committee on Mitigating Wetland Losses, National Academy Press, Washington, DC, 2001.

6. Engelhardt, K.A.M. and Ritchie, M.E., Effects of macrophyte species richness on ecosystem functioning and services. Nature, 411: 687-689, 2001.

7. Odum, H.T. and Pigeon, P. eds., A Tropical Rain Forest. AEC Division of Technical Information, Oak Ridge, TN, 1970.

8. Likens, G.E. et al., Biogeochemistry of a Forested Ecosystem. Springer-Verlag, New York, 1977.

9. Sullivan, T.J. Whole-ecosystem nitrogen effects research in Europe. Env. Sci. \& Tech., 27: 1482-1486, 1993. 


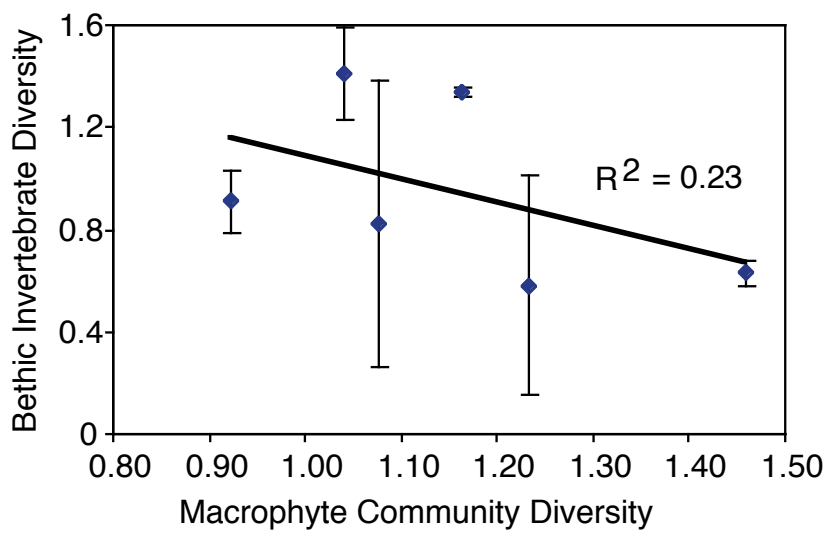

Figure 11. Relationship of benthic invertebrate diversity to macrophyte community diversity index (CDI). Each data point is one of two 1-ha basins for years 1997-99.

10. Beier, C., and Rasmussen, L., Effects of wholeecosystem manipulations on ecosystem internal processes. Trends in Ecology and Evolution, 9: 218223, 1994.

11. Schindler, D.W., Evolution of phosphorus limitation in lakes. Science, 195: 260-262, 1977.
12. Schindler, D.E., et al., Influence of food web structure on carbon exchange between lakes and the atmosphere. Science, 227: 248-251, 1997.

13. Carpenter, S.R. et al.. Chlorophyll variability, nutrient input and grazing: evidence from whole-lake experiments. Ecology, 77: 725-735, 1996.

14. Carpenter, S.R. et al., Impact of dissolved organic carbon, phophorus and grazing on phytoplankton biomass and production in experimental lakes. Limnol Oceanogr., 43: 73-80, 1998a.

15. Odum, H.T. et al., Recycling treated sewage through cypress wetlands. In: F.M. D’Itri (Ed.), Wastewater renovation and reuse. Marcel Dekker Press, New York, pp. 35-67, 1977.

16. Mitsch, W.J. et al., Phosphorus retention in constructed freshwater riparian marshes. Ecol. Appl., 5: 830-845, 1995.

17. Carpemter, S.R. The need for large-scale experiments to assess and predict the response of ecosystems to perturbation, in Successes, Limitations, and Frontiers of Ecosystem Science, Pace, M.L. and Groffman, P.M., Eds., Springer-Verlag, New York, 1998, pp. 287-312.

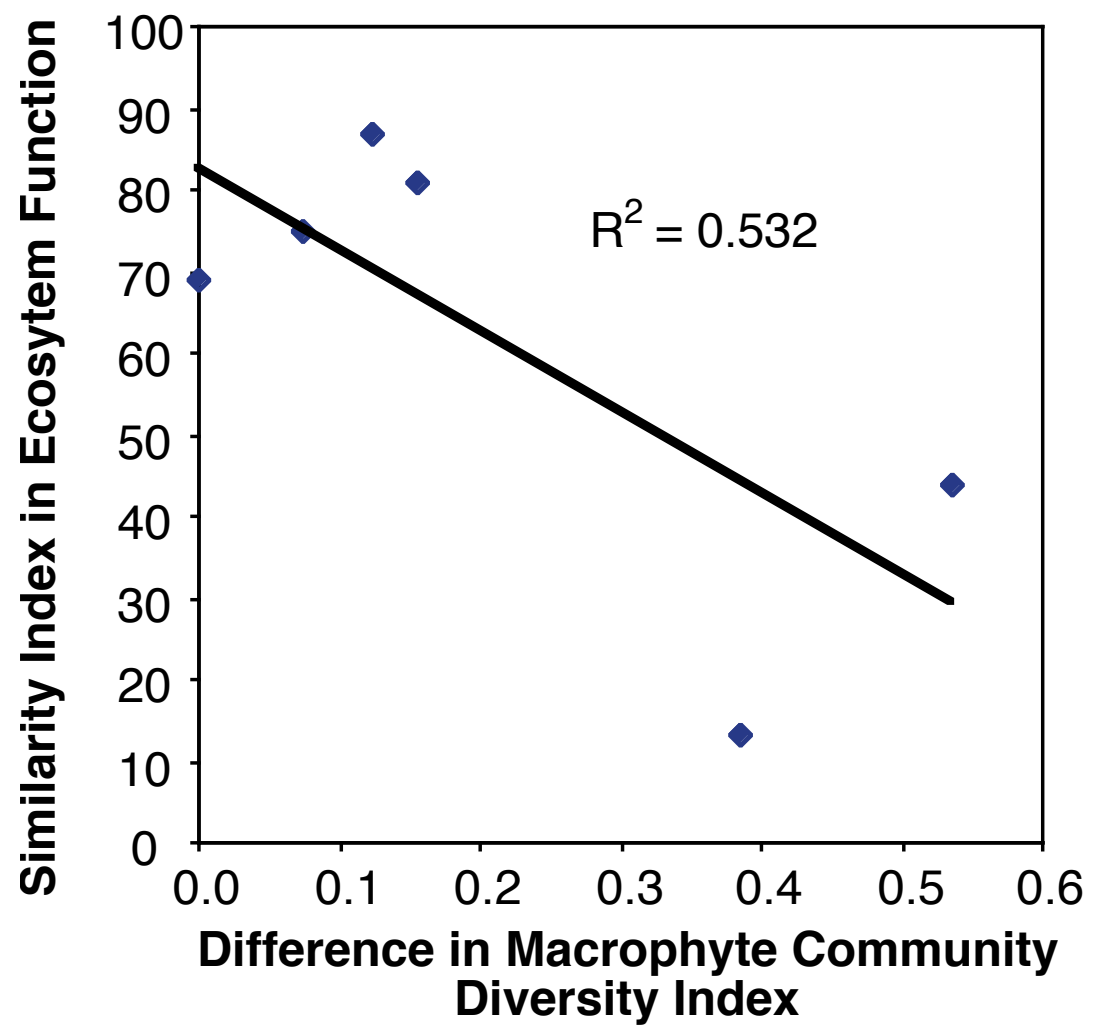

Figure 8. Plot of ecosystem function similarity index (SI) between the two wetlands versus difference in macrophyte community diversity indices (CDI) for the same years. Data illustrate that when the two wetlands were different in CDI, they were also dissimilar in ecosystem function. When wetlands had similar CDI, their ecosystem function was similar. 
Table 5. Comparison of amphibians, reptiles, and fish caught in 20 traps in two wetlands in spring of 2000. Numbers are organism caught per trap-day.

\begin{tabular}{lll}
\hline Species & $\begin{array}{c}\text { Wetland 1 } \\
\text { (mean } \pm \text { S.E.) }\end{array}$ & $\begin{array}{c}\text { Wetland 2 } \\
\text { (mean } \pm \text { S.E.) }\end{array}$ \\
\hline Rana catesbeiana & $0.015 \pm 0.006$ & $0.14 \pm 0.024^{\star}$ \\
Rana clamitans & $0.03 \pm 0.01$ & $0.02 \pm 0.01$ \\
Nerodia sipedon & $0.006 \pm 0.004$ & $0.023 \pm 0.008^{\star}$ \\
Lepomis cyanellus & $21 \pm 2$ & $34 \pm 3^{\star}$ \\
\hline
\end{tabular}

* indicates significantly higher number compared to Wetland $1(\alpha=0.05)$

18. Carpenter, S.R., et al., Evaluating alternative explanations in ecosystem experiments. Ecosystems, 1: 335-344, 1998b.

19. Mitsch, W.J. and Kaltenborn, K.S., Effects of copper sulfate application on diel dissolved oxygen and metabolism in the Fox Chain of Lakes. Trans. Ill. State Acad. Sci., 73: 55-64, 1980.

20. U.S. Environmental Protection Agency, Handbook for methods in water and wastewater analysis. U.S. Environmental Protection Agency, Cincinnati, Ohio, 1983.

21. American Public Health Association, Standard Methods for the Analysis of Wastewater, 17th ed. APHA, Washington, DC, 1989.

22. Wu, X., and Mitsch, W.J., Spatial and temporal patterns of alga in newly constructed freshwater wetlands. Wetlands, 18: 9-20, 1998.

23. Tilman, D., Wedin, D. and Knops, J., Productivity and sustainability influenced by biodiversity in grassland ecosystems. Nature, 379: 718-720, 1996.

24. Tilman, D., Knops, J., Wedin, D., Reich, P., Ritchie, M. and Siemann, E., The influence of functional diversity and composition on ecosystem processes. Science, 277: 1300-1302, 1998.

25. Moore, D.R.J. et al., Conservation of wetlands: Do infertile wetlands deserve a high priority. Biological Conservation, 47: 203-217, 1989.

26. Mitsch, W.J.,and Gosselink, J.G., Wetlands, 3rd ed. John Wiley \& Sons, Inc., New York, 2000.

27. Mitsch, W.J. and Jørgensen, S.E., Ecological Engineering and Ecosystem Restoration. J. Wiley, New York, 2004.
28. Tanner, C.C., Plants for constructed wetland treatment systems - A comparison of the growth and nutrient uptake of eight emergent species. Ecol. Eng., 7: 59-83, 1996.

29. Braskerud, B.C., The influence of vegetation on sedimentation and resuspension of soil particles in small constructed wetlands. Jour. Environ. Qual., 30: 1447-1457, 2001.

30. Worm, B. et al. Consumer versus resource control of species diversity and ecosystem functioning. Nature 417: 848-851, 2002.

31. Gifford, A.M., The effect of macrophyte planting on amphibian and fish community use of two created wetland ecosystems in central Ohio. M.S. Thesis, The Ohio State University, Columbus, Ohio, 2002.

32. Pace, M.L., Getting it right and wrong: Extrapolations across experimental scales. In: R.H. Gardner, W.M. Kem, V.S. Kennedy, and J. Petersen (Eds.), Scaling relations in experimental ecology. Columbia University Press, New York, pp. 157-177, 2001.

33. Ahn, C., and Mitsch, W.J., Scaling considerations of mesocosm wetlands in simulating large created freshwater marshes. Ecol. Eng., 18: 327-342, 2002.

34. Jones, C.A., Lawton, J.H. and Shachak, M., Organisms as ecosystem engineers. Oikos, 69: 373386, 1994.

35. Jones, C.A., Lawton, J.H. and Shachak, M., Positive and negative effects of organisms as physical ecosystem engineers. Ecology, 78: 1946-1957. 